\title{
A Preliminary Report of Collembola (Arthropoda: Collembola) from Northern Hill Region of Chhattisgarh, India
}

\author{
Dharmpal Kerketta ${ }^{1}$, Ramesh Singh $\operatorname{Yadav}^{2} *$ and G.P. Painkra ${ }^{3}$ \\ ${ }^{1}$ Indira Gandhi Agricultural University, KVK Surguja, Ambikapur (C.G.), India \\ ${ }^{2}$ Independent Researcher (Entomology), Ghazipur, Uttar Pradesh, India \\ ${ }^{3}$ Indira Gandhi Agricultural University, RMDCARS Ajirma, Ambikapur (C.G.), India \\ *Corresponding author
}

\section{A B S T R A C T}

\section{Keywords \\ Arthropoda, Collembola, Chhattisgarh, First record, Ranghagh, Preliminary \\ Article Info \\ Accepted: \\ 24 August 2018 \\ Available Online: \\ 10 September 2018}

The present study was made to assess the Collembola fauna of the Northern Hill Region of Chhattisgarh, India. The 12 species from 10 genera of epigeic collembola were recorded from two different habitats of the region and 8 genera namely Seira, Entomobrya, Homidia, Lepidocyrtus, Sinella, Yossia, Pseudosalina and Salina were firstly recorded from the Chhattisgarh. They are rich in organic soil and leave litters. Subfamily Lepidocyrtinae (Lepidocyrtus) was dominating group whereas subfamily Paronellinae was the diverse subfamily over all during the whole survey.

\section{Introduction}

The collembolans (springtails) are micro Soil Arthropods and the most abundant apterygote insect in the soil and constitute an important component of soil mesofauna in almost all type of ecosystems. There are about 8279 described species of collembola worldwide, (Belinger et al., 2016). In case of Indian Collembola represent 342 species in 113 genera under 20 different families (Mandal 2018). They found in wet areas as well as in dry ecosystems from arctic and alpine tundra to deserts and tropical rain forests. Collembola are beneficial to the health of soil and are generally 1-3 mm long in size. The majority of springtails feed on various fungal hyphae or decaying plant material (organic material). Such activities are vital in the functioning of ecosystems and maintaining of soil health and above ground productivity, both in natural i.e. forest and human altered (agricultural) ecosystem.

The literatures are very silent regarding collembolan reports from the Chhattisgarh of India. The State Chhattisgarh contributed very negligible number of Collembola fauna i.e. only 6 species for Indian Collembola heritage (Mandal, 2018). The study of various aspects of collembolan ecology and diversity in Surguja district of Chhattisgarh is initiated. 
The aim of present study was to observe the diversity of springtails in different habitat of Northern Hill Region of Chhattisgarh.

\section{Materials and Methods}

The present study was carried out at two locations of the Northern Hill Region of Chhattisgarh namely, Litchi Orchard of IGKV- Rajmohini Devi College of Agricultural and Research Station, Ambikapur and Ranghagh forest Nursery in Chendra village of Surguja District of Chhattisgarh. The Litchi orchard of IGKV- Rajmohini Devi College of Agricultural and Research Station, Ambikapur is situated at $623 \mathrm{Mtr}$. above the mean sea level and lies at $23.10^{\circ} \mathrm{N}$ latitude and $83.15^{\circ} \mathrm{E}$ longitudes, whereas Ranghagh forest nursery is situated at $23.0658^{\circ} \mathrm{N}$ Latitude and $83.3228^{\circ}$ E Longitude respectively (Fig. 1). The average temperature and rainfall of region are $23.90^{\circ}$ Celsius and $1358.30 \mathrm{~mm}$ annually respectively.

The Litchi Orchard (site-I) was heavily littered (but not fully decomposed) which was wetted by seepage of regular irrigation channel. More or less same situation was also at Ranghagh Forest Nursery, but in Ranghagh nursery litters were moistened by regular flow of fall water and soil was stony with litter fall. The Collembola were collected during month of March 2018 at morning hours (06 AM to 08 AM) through the aspirator (Fig. 2). The collection methods were followed to Yadav (2017a) and Yadav et al., (2018a). The collected materials were frequently transferred to the vial containing $60 \%$ alcohol. Soil litters were also carried for extraction of Collembolans in the laboratory through Tullgren Funnel method (Tullgren, 1918) (Fig. 3). These collected Collembola were also transfer into vial containing $70 \%$ of alcohol.

All the collected materials were shorted out under stereo zoom microscope (CZM6) and Labovision (AXL) in the laboratory. The final identification was made by temporary slide preparation method with the help of standard keys of Christiansen and Bellinger (1992), Hazra (2015) and Yadav et al., (2018b).

\section{Results and Discussion}

A total of 560 individuals of epigeic Collembola of 12 species from 10 genera were identified from 4 different subfamilies from two sites of Northern Hill Region of Chhattisgarh after intensive surveys during March 2018 (Table 1) and Figure 4 and 5. The subfamily wise distribution of epigeic Collembola are given in Figure 5 of the both sites of this region of Chhattisgarh. The Collembola fauna of the subfamily Lepidocyrtinae was dominated at the both sites over all in respect of population abundance while Paronellinae (6 spp) was diverse subfamily in respect of generic compositions followed by Lepidocyrtinae (3) and Entmobryinae (2sp) and Seirinae with only 1 genera.

The population abundance at generic level was also recorded during the survey. The highest population was recorded as Lepidocyrtus sp2 (16\%) followed by Lepidocyrtus spl (15\%) Entomobrya sp. (11\%), Sinella sp. and Yossia sp. (10\% each), Salina indica (9\%), Callyntrura spl (7\%), Dicranocentroides indica (6\%), Callyntrura sp2 (5), Pseudosalina sp and Homidia sp (4\% each) and Seira sp (3\%) were recorded during the study (Fig. 6).

In Indian checklist of Collembola, state of Chhattisgarh added only 6 species till date (Mandal, 2018). The present study contributed 12 species of 10 genera namely Seira, Entomobrya, Homidia, Lepidocyrtus, Sinella, Dicranocentroides, Callyntrura, Yossia, Pseudosalina \& Salina. Yadav (2017a), Raghuraman et al., (2010), Yadav et al., (2018a), Yadav (2017b), Yadav and Singh 
(2009) and Yadav (2017c) have recorded very considerable number of the Collembola fauna from the adjoining province to the Chhattisgarh. In these record 8 genera are firstly recorded from the state whereas Mandal
(2018) listed 6 species from two genera namely Callyntrura and Dicranocentroides. The study reveals that this region has also two endemic species of Collembola viz. D. Indica and S. Indica.

Table.1 Checklist of epigeic Collembola of Northern Hill Region of Chhattisgarh, India

\begin{tabular}{|c|c|c|c|}
\hline S.N. & Теха & $\begin{array}{l}\text { RMDCARS (Litchi } \\
\text { Orchard) (Site I) }\end{array}$ & $\begin{array}{l}\text { Ranghagh Forest } \\
\text { Nursery (Site II) }\end{array}$ \\
\hline 1. & $\begin{array}{l}\text { Seirinae } \\
\text { Seira } \mathrm{sp}\end{array}$ & + & ++ \\
\hline 2. & $\begin{array}{l}\text { Entomobryinae } \\
\text { Entomobrya } \mathrm{sp} \\
\text { Homidia } \mathrm{sp}\end{array}$ & $\begin{array}{l}+ \\
-\end{array}$ & $\begin{array}{c}+++ \\
++\end{array}$ \\
\hline 3. & $\begin{array}{l}\text { Lepidocyrtinae } \\
\text { Lepidocyrtus } \mathrm{sp} 1 \\
\text { Lepidocyrtus } \mathrm{sp} 2 \\
\text { Sinella } \mathrm{sp}\end{array}$ & $\begin{array}{l}+ \\
+ \\
+\end{array}$ & $\begin{array}{c}+++ \\
++ \\
-\end{array}$ \\
\hline 4. & $\begin{array}{l}\text { Paronallinae: } \\
\text { Dicranocentroides indica } \\
\text { Yossia } \mathrm{sp} \\
\text { Callyntrura } \mathrm{sp} 1 \\
\text { Callyntrura } \mathrm{sp} 2 \\
\text { Pseudosalina } \mathrm{sp} . \\
\text { Salina indica }\end{array}$ & $\begin{array}{l}+ \\
- \\
- \\
- \\
- \\
+ \\
-\end{array}$ & $\begin{array}{c}- \\
++ \\
+++ \\
++ \\
+ \\
+ \\
++\end{array}$ \\
\hline
\end{tabular}

Fig.1 Habitat of Survey Site (Site I Above and Site II below)

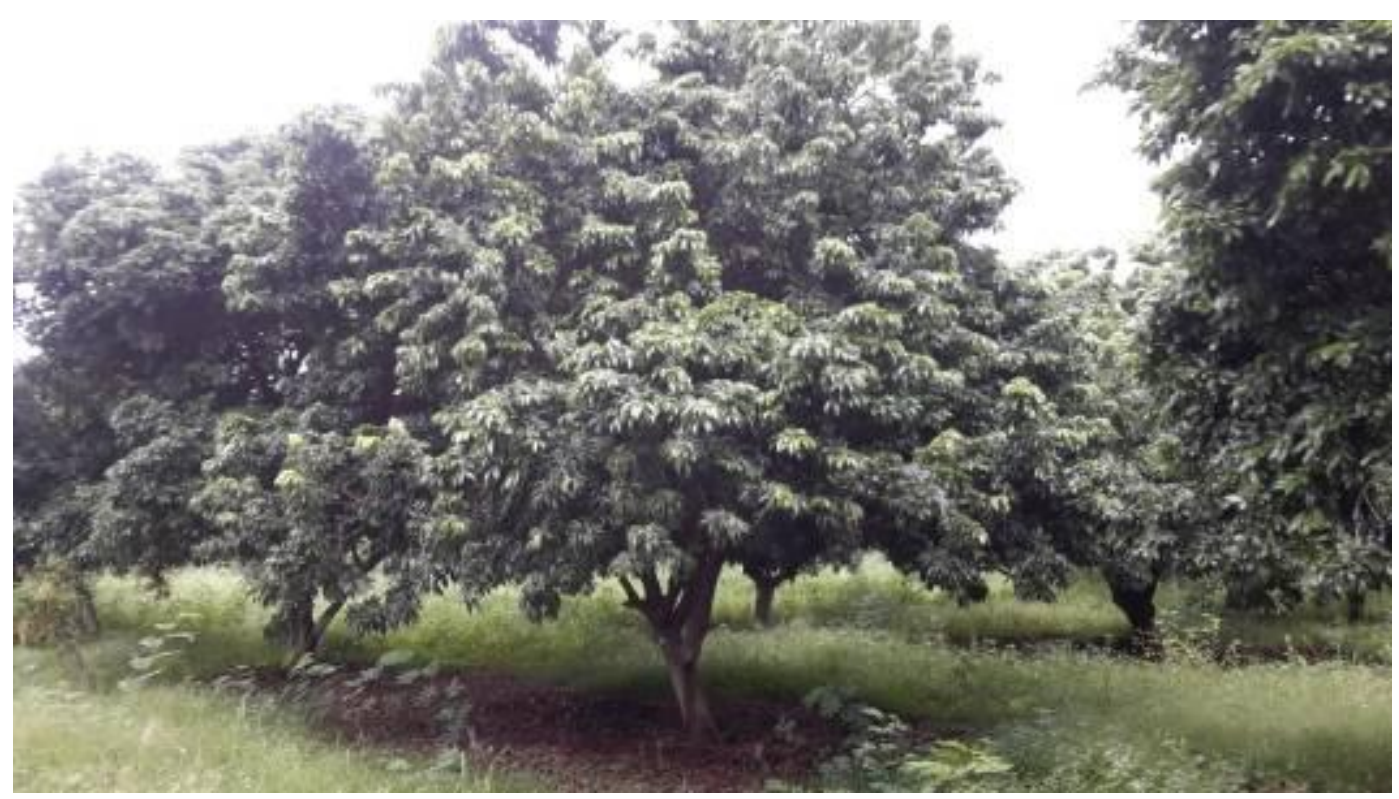




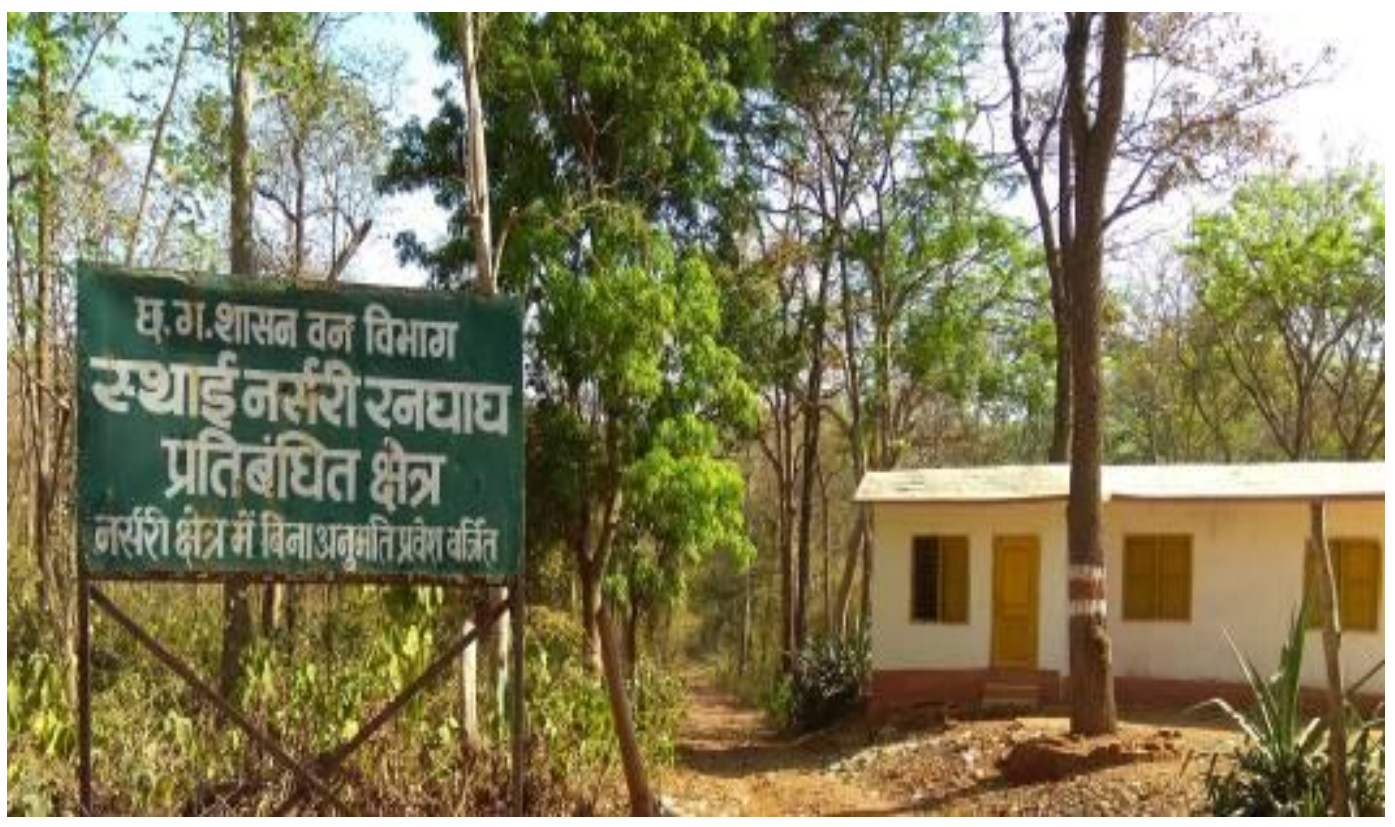

Fig.2 Collection of Fauna

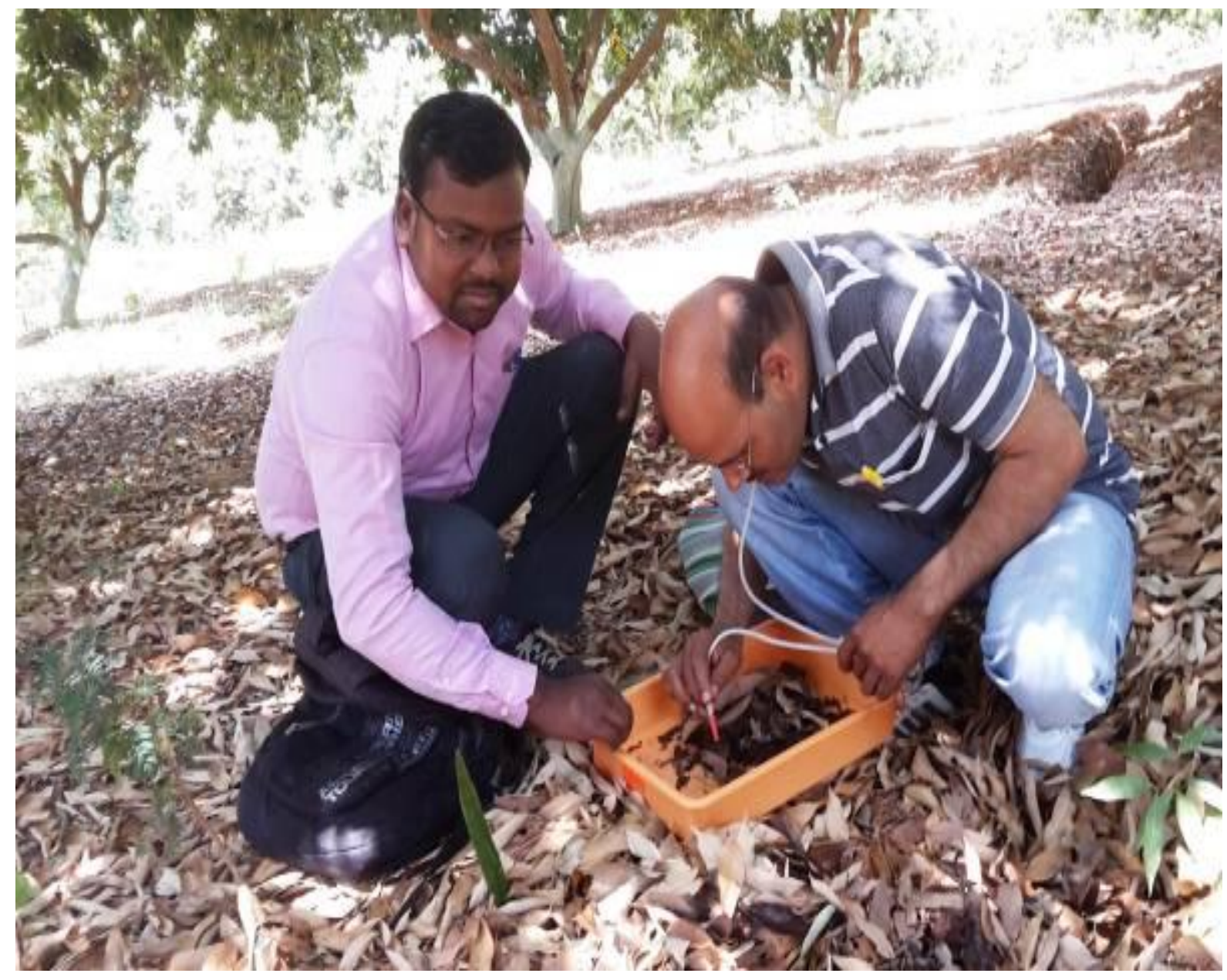


Fig.3 Extraction of leaf litter

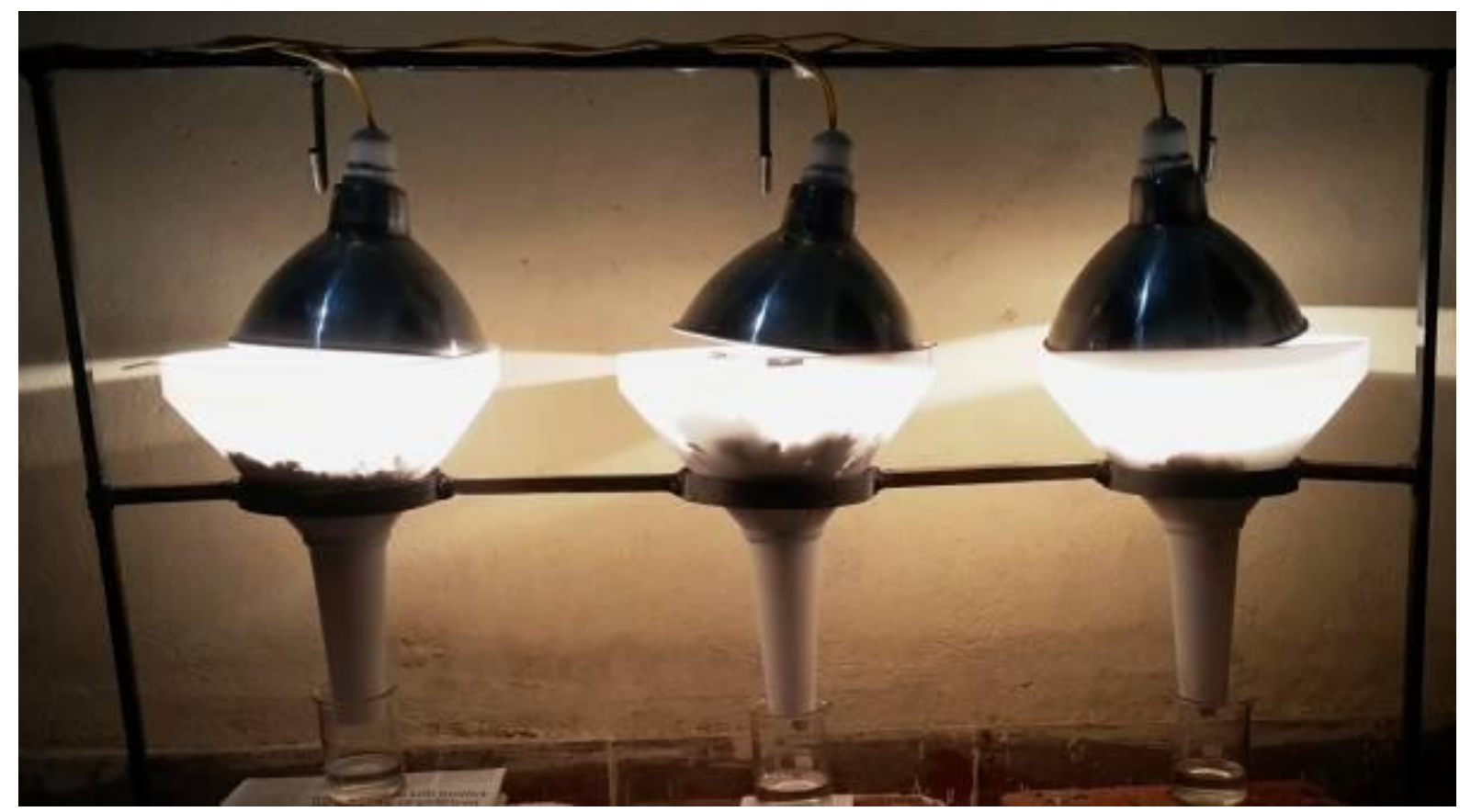

Fig.4 Biodiversity of the Collembola fauna

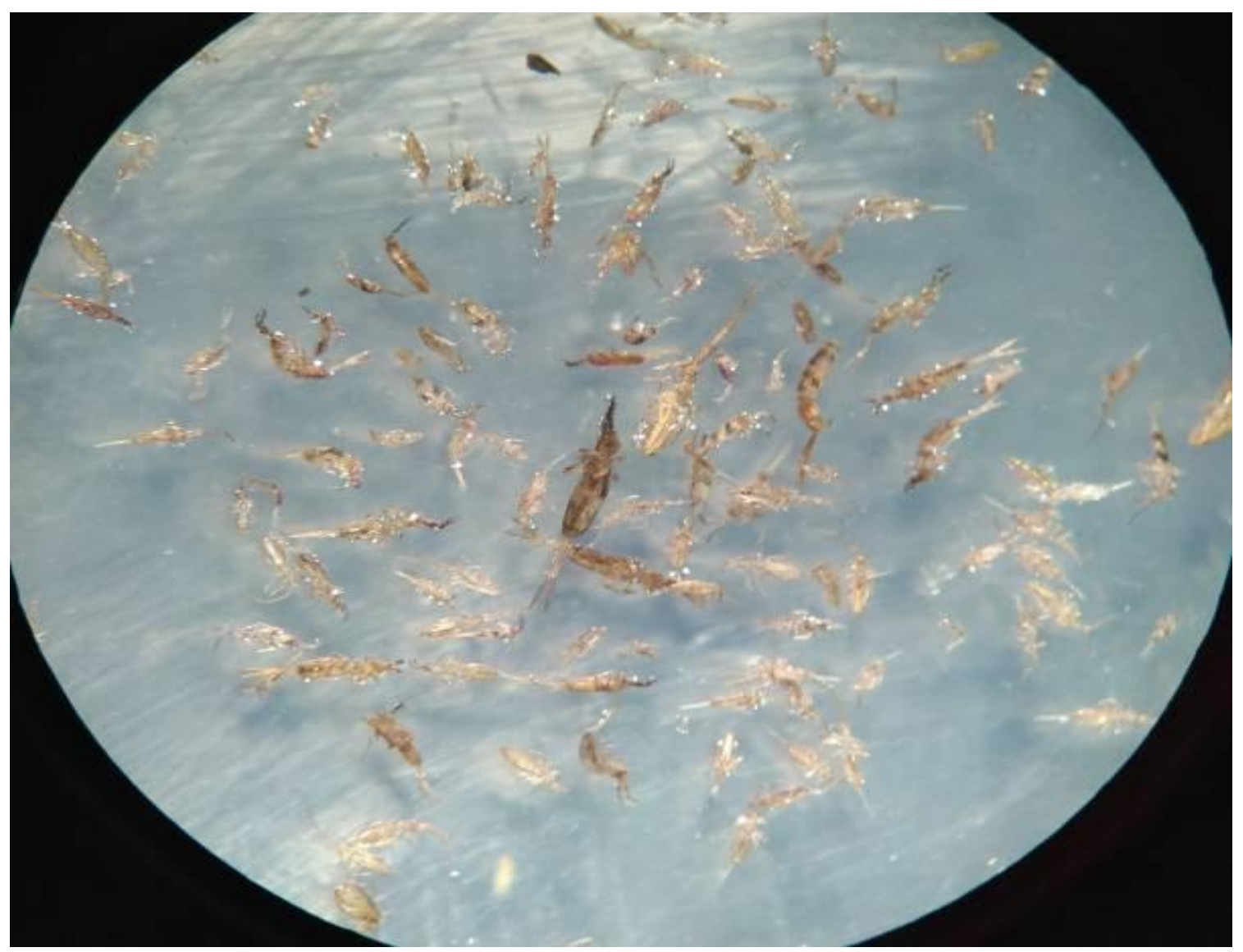


Fig.5 A. Entomobrya, B. Salina, C. Seira, D. Callyntrura 1, E. Callyntrura II, F. Homidia G. Yossia

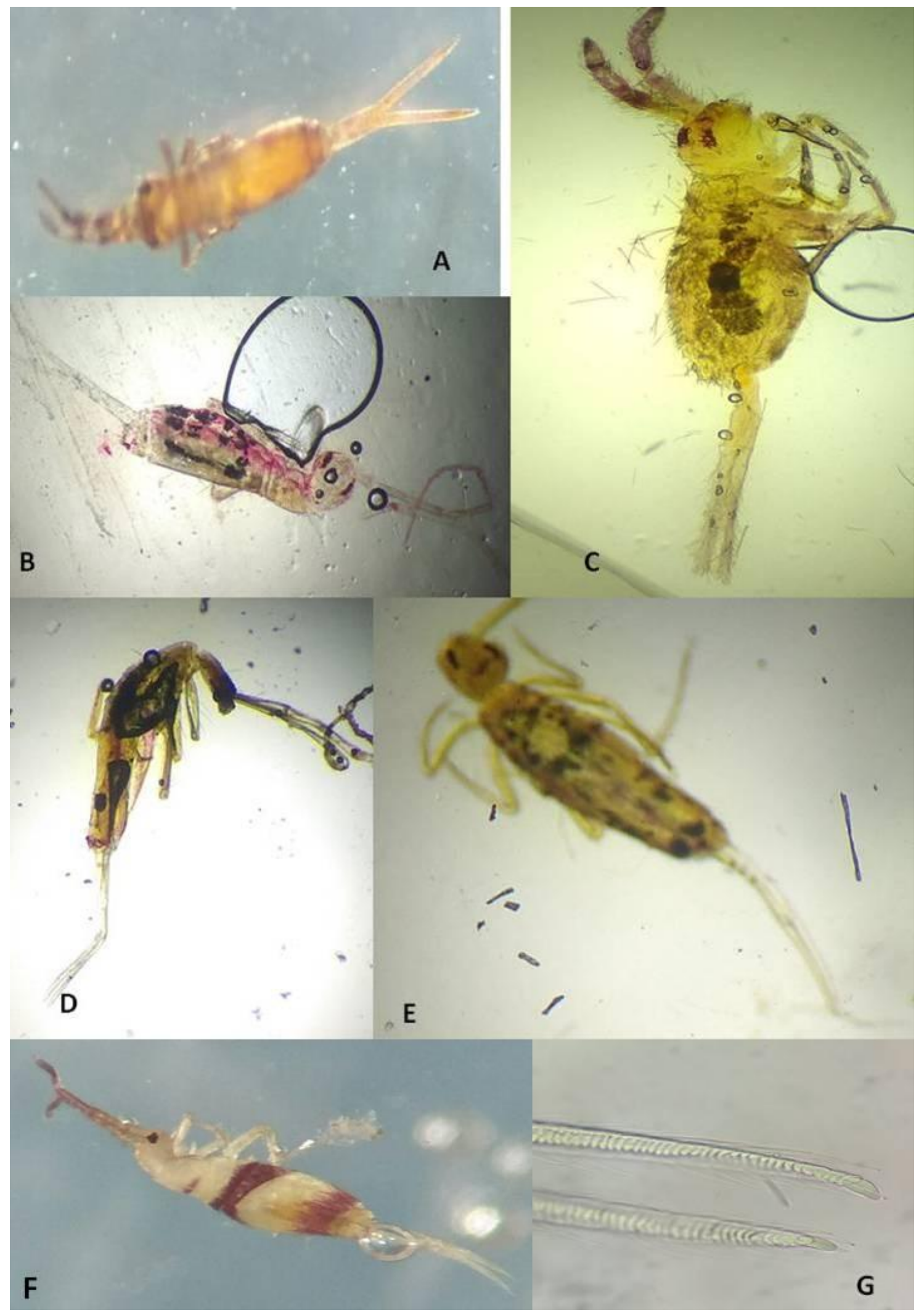


Fig.6 Population abundance of Collembola at NHR of Chhattisgarh

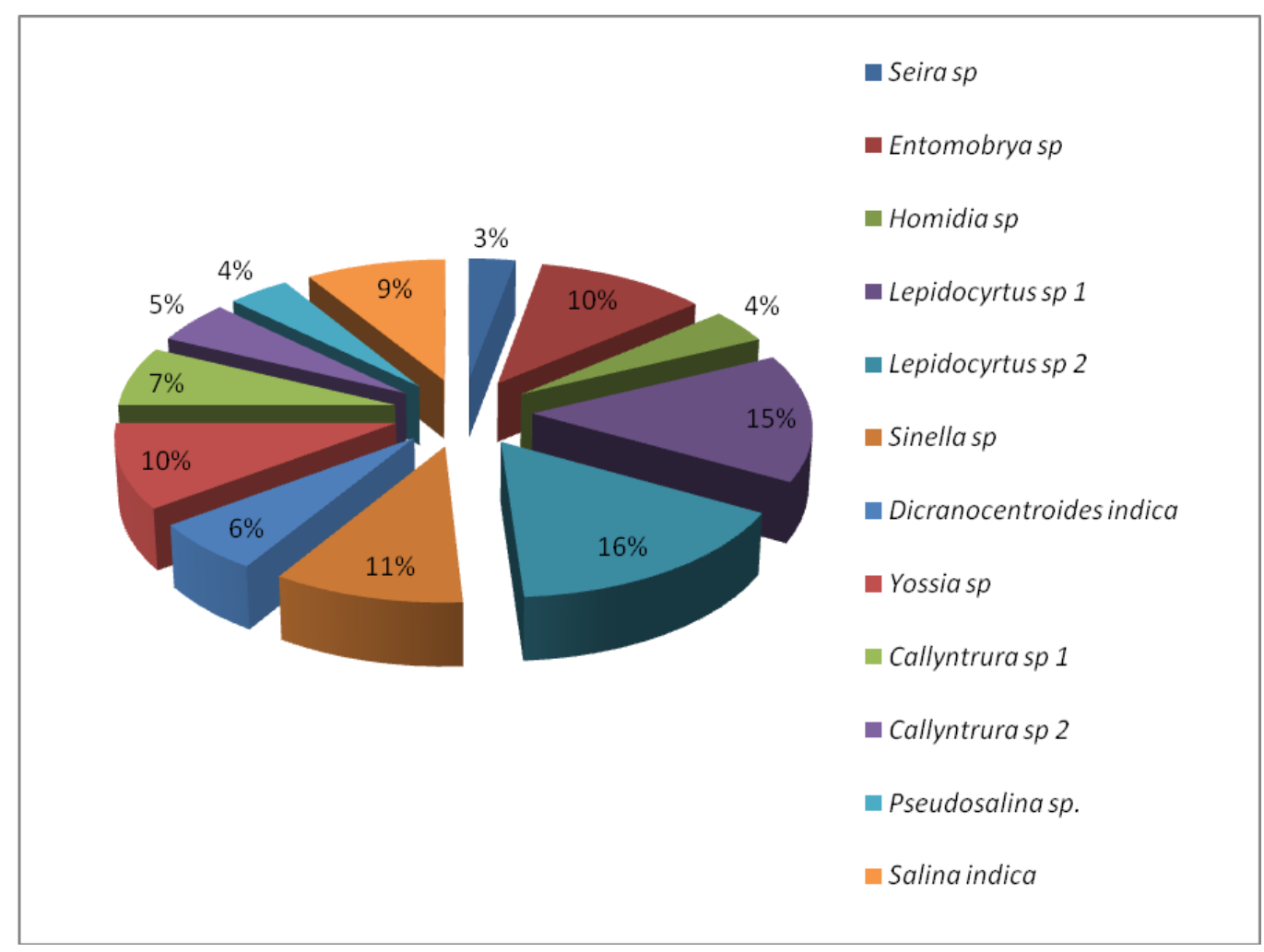

If site wise comparison seen, the site-I has lesser number of collembolan as compare to site-II. It is mainly due to more organic matter contents and moisture in the litter and soil of site-II. Yadav et al., (2018c), Detsis (2000) and Christiansen and Bellinger (1980) have also recorded that organic horizon contains more number of Collembola in the India and abroad.

Family Entomobryidae (subfamily Entomobryinae and Lepidocyrtinae) and Paronellidae (subfamily Paronellinae) are the first and second dominating family group respectively while rests are lesser. Yadav (2017b) and Raghuraman et al., (2010) and Yadav et al., (2018a) also reported somewhat similar trend from the country. Family Paronellidae (subfamily Paronellinae) contributed higher number of individuals from Northern hill region of Chhattisgarh whereas (Yadav et al., 2018a) recorded
Entomobryidae from W.B., India genus Lepidocyrtus, was dominating over the all (Yadav, 2017a), Raghuraman et al., (2010) and Mandal (2014).

\section{Acknowledgement}

We wish to extend our gratitude to Dean, Rajmohini Devi Agricultural College and Research station, Ambikapur Surguja Chhattisgarh and Section Head, Entomology department of RMDCARS for providing necessary laboratory facilities. Thanks are also due to forest official and care taker of Ranghagh Nursery for allowing to collecting the fauna.

\section{References}

Bellinger, P.F., Christiansen, K.A. and Janssens, F. (2016). Checklist of world 
Collembola. www.collembola.org (Accessed on 26 June 2016).

Christansen K. and Bellinger P. (1980). The Collembola of North America: North of the Rio Grande. Grinnel College, Frinnel 1A.

Christiansen, K. \& P. Bellinger (1992). Insects of Hawaii. Vol. 15, (Collembola). University of Hawaii Press, Hawaii, vii+445pp.

Detsis V. (2000). Vertical distribution of Collembola in deciduous forests under mediterranean climatic conditions. Belgium Journal of Zoology, 130 (supplement 1): 55-59.

Hazra, A.K. (2015). A review on Paronellinae (Collembola: Paronellidae) of India. Record Zoological survey of India, Occassional paper No. 368; 1-63.

Mandal, G.P. (2014). New records of Collembola (Hexapoda) from Hazaribagh National Park, Jharkhand, India. Biological Forum: An International Journal 6 (2): 197-202.

Mandal, G.P. (2018). Collembola of IndiaAn Updated Checklist. Halters, 9: 116130.

Raghuraman, M., Yadav, R. S. and Singh J. (2010). Biodiversity of Collembola at Varanasi. Indian Journal of Entomology, 72 (4): 333-336.

Tullgren, A. (1918). Ein sehr einfacher Ausleseapparat für terricole Tierfaunen. Zeitschrift für angewandte Entomologie 4: $149-150$.

Yadav, R.S. (2017a). Preliminary Checklist of Springtails (Arthropoda: Collembola) of Uttar Pradesh, India. Journal of Threatened Taxa 9(12): 11054-11059.
Yadav, R. Prasad, S. and Kumar, D. (2018a). Diversity of epigeic Collembola of Bibhutibhusan Wildlife Sanctuary, North 24 Parganas, West Bengal (India). International Journal of Fauna and Biological Studies; 5 (2): 17-21.

Yadav, R. S. (2017b). First records of a Collembola and their diversity measurement from B.A.U. Ranchi, Jharkhand. Journal of Entomology and Zoology Studies 5 (5): 1724-1727.

Yadav, R. S. (2017c). Computation of the biodiversity of some springtails of Uttar Pradesh. Journal of Experimental Zoology India, 20 (supl. 1): 1337-1341.

Yadav, R. S., Kerketta D., Painkra, G.P. and Kumar, D. (2018b). Basics of the study of biodiversity for the Collembola (Hexapoda: Collembola): A need for beginners. In: Research Trends in Forestry Sciences (Ed. Johar, V.). AkiNik Publication New Delhi. (Accepted).

Yadav, R. S., Kumar, D., Kerketta D. and Prasad, S. (2018c). Vertical distribution of Collembola (Arthropoda: Collembola) at Varanasi, India. International Journal of Current Microbiology and Applied Sciences 7 (3): 609-613.

Yadav, R.S. and Singh J. (2009). Biodiversity of soil arthropods under Mango (Mangifera indica L.) orchard ecosystem in Varanasi, Uttar Pradesh. Environment and Ecology 27(3A): 1228-1230.

\section{How to cite this article:}

Dharmpal Kerketta, Ramesh Singh Yadav and Painkra, G.P. 2018. A Preliminary Report of Collembola (Arthropoda: Collembola) from Northern Hill Region of Chhattisgarh, India. Int.J.Curr.Microbiol.App.Sci. 7(09): 3385-3392. doi: https://doi.org/10.20546/ijcmas.2018.709.420 